\title{
Development cooperation in water and sanitation: is it based on the human rights framework?
}

\author{
Cooperação para o desenvolvimento em água \\ e esgotamento sanitário: é baseada no quadro dos direitos humanos?
}

Colin Brown ${ }^{1}$

Léo Heller ${ }^{1}$

${ }^{1}$ Centro de Pesquisas René Rachou, Fundação Oswaldo Cruz. Av. Augusto de Lima 1715, Barro Preto. 30190002 Belo Horizonte MG Brasil.colin.brown@ cpqrr.fiocruz.br

\begin{abstract}
The water and sanitation sector is verifiably receiving increased attention and funding through international development cooperation. Not least because of the way that it affects incentives and institutions in partner countries, development cooperation can have either positive or negative effects on human rights though. The consolidated frameworks for the human rights to water and sanitation is becoming linked to the international community's coordinated development efforts, as evidenced notably in the 2030 Agenda for Sustainable Development. However, a review of major funders' official policies for development cooperation in the sector suggests that many only partially endorse the frameworks for the human rights to water and sanitation. An observation of development cooperation flows to the sector allows the hypothesis to be advanced that worldwide inequalities in access to these services may be reduced through a full and clear application of the human rights framework in development cooperation activities. The article presents findings of this research and explores key stakes for development cooperation in the water and sanitation sector that are relevant for their ability to either negatively or positively contribute to the realization of human rights.
\end{abstract}

Key words Development cooperation, Human rights, Water, Sanitation, Policy review
Resumo O setor de água e esgotos vem recebendo crescente atenção e financiamento por meio da cooperação internacional para o desenvolvimento. Não apenas devido à forma como tal cooperação afeta incentivos e instituições nos países parceiros, esta pode trazer efeitos positivos ou negativos para os direitos humanos. O marco consolidado para os direitos humanos à água e ao esgotamento sanitário vem sendo associado aos esforços da cooperação para o desenvolvimento promovido pela comunidade internacional, como evidenciado na Agenda para o Desenvolvimento Sustentável de 2030. No entanto, uma revisão das políticas oficiais dos maiores financiadores no setor sugere que muitos deles endossam apenas parcialmente os marcos dos direitos humanos à água e aos esgotos. A observação dos fluxos dessa cooperação para o setor permite formular a hipótese de que as desigualdades no acesso a esses serviços em várias partes do mundo podem ser reduzidas com a plena e clara aplicação do marco dos direitos humanos nas atividades de cooperação para o desenvolvimento. O artigo apresenta achados dessa pesquisa e explora desafios chave para a cooperação para o desenvolvimento no setor de água e esgotos que são relevantes para impactar tanto negativamente quanto positivamente os direitos humanos.

Palavras-chave Cooperação para o desenvolvimento, Direitos humanos, Água, Saneamento, Revisão de políticas 


\section{Introduction}

Development cooperation can have either positive or negative effects on human rights, not least because of the way that it affects incentives and institutions in partner countries. "Partner" State or country is used in the present article, although "recipient" State or country is often used. The intention here is to suggest a more horizontal relationship between the funder and the State that receives funding. Conversely, human rights can guide policies for development cooperation at a variety of levels. This has been particularly evidenced over the past several decades in the water and sanitation (WATSAN) sector. Development cooperation has long been identified in many international spheres as an essential element to promoting prosperity and alleviating poverty, most notably in article 22 of the Universal Declaration of Human Rights. There is a relatively long history, dating back to $1976^{1}$, of internationally organized efforts linking improved access to WATSAN services worldwide to multilateral development cooperation. Still today, development cooperation is responsible for a significant share of total funding for WATSAN services in the Global South. In addition, development cooperation practices have come to establish a certain benchmark for conduct in this sector, not only for funders but also on the part of governmental agencies of partner countries.

However, the frameworks to define how national and international actors should contribute to improving access to WATSAN through development cooperation have been mutative over the years ${ }^{2}$. For instance, although the human right to water was famously referenced in the 1992 Dublin Conference, in retrospect it has been recognized that, on the whole, development cooperation activities in that decade might have negatively impacted on the human rights to water and sanitation (HRtWS). Notably, aspects such as affordability of services, country ownership, and access for the most disadvantaged populations were brought to the forefront. Until that decade, many negative impacts could have been owing at least in part to the fact that the framework for the human right to water was then an informal patchwork. At the same time, other overarching, aggravating factors included commercial interests, the influence of multinational corporations, and the broad foreign policy of States that guided how and with whom they chose to cooperate.

Since 2002, a framework for the HRtWS has been consolidated with increasing precision by multiple United Nations (UN) entities ${ }^{3,4}$. The UN 2030 Agenda for Sustainable Development (via Goal 6 and, more specifically, target 6.a) is a renewed commitment of States to realize the HRtWS, in part through significant contributions from development cooperation activities. The standalone mention of the HRtWS in this agenda, as articulated in "Transforming Our World"5 undoubtedly invokes the greater framework of the economic, cultural and social rights that, for decades, has emphasized the importance of international development cooperation for the realization of these rights. For some this may be cause for hope, since the failure of several developing countries, including the Least Developed Countries (LDCs), to meet the Millennium Development Goal (MDG) on access to water and sanitation can supposedly be attributed to an international failure to operationalize sufficient and effective development cooperation ${ }^{6}$.

In this context, the present article presents summary reflections on this subject, benefiting in large part from the preliminary review set forth in the recent report (A/71/302) of the UN Special Rapporteur on the human rights to safe drinking water and sanitation ${ }^{7}$. To inform this discussion and better understand the global political landscape, which is replete with reiterated commitments but uneven progress, the article reviews relevant international legal standards and commitments, assesses development cooperation activity in the WATSAN sector, and examines policy documents of States and multilateral funders. In doing so, this analysis aims to identify to what extent and in what form the frameworks for the HRtWS are being incorporated by major funders.

\section{Human rights in development cooperation}

\section{Relevant obligations of States}

The HRtWS derive from the right to an adequate standard of living, whose enshrinement in article 11 of the International Covenant on Economic, Social and Cultural Rights (ICESCR) implies certain binding legal obligations pursuant to Article 2(1) of that same Covenant. Mainly, each State Party to that Covenant is committed to taking steps, individually and through international assistance and cooperation, especially economic and technical, to achieve the full realization of the rights recognized in the Covenant. Moreover, the process through which States must 
periodically report to the CESCR on treaty compliance requires them to indicate the impact of their cooperation "on the full realization of each of the Covenant rights" in other countries, and especially developing countries ${ }^{8}$.

Although some interpretations of ICESCR article 2(1) have raised claims that State parties are merely obliged to request international assistance where needed, this viewpoint runs in contradiction to the spirit of many other authoritative interpretations of States' obligations regarding international cooperation ${ }^{9}$. Indeed, in a broader interpretation of the article it is possible to infer States' extraterritorial obligations to contribute to the realization of human rights outside of their national territory. This interpretation is supported by several provisions of international law that clearly require international cooperation for the realization of economic, social and cultural rights, including the UN Charter (Article 56), the Universal Declaration of Human Rights (Articles 22 and 28), and the Convention on the Rights of the Child (Articles 4, 24(4) and 28(3)).

Each State Party is also bound to use the maximum of its available resources and aim to progressively realize those human rights in the ICESCR. Those States that are unable to fulfil the obligation to realize the economic, social and cultural rights must make plans and strategies and seek necessary international cooperation to do so. Conversely, those States capable of providing support to other States through international assistance and cooperation must do so in a manner consistent with their extraterritorial obligations to fulfil economic, social and cultural rights.

\section{Situating non-State actors in a State-centric international legal framework}

The role and responsibilities of non-State actors in realizing - and not aggravating - human rights via development cooperation have not been the subject of as conclusive and consensual discussions by UN organisms. A set of Guiding Principles on Business and Human Rights has been formulated albeit they are of a non-binding character, like other resolutions of the UN Human Rights Council (UNHRC) and UNGA ${ }^{10}$. In the context of a State-centric international legal framework, non-State actors are more commonly attributed with human rights responsibilities instead of obligations. Critiques are waged against the current legal framework, however, on the grounds that it is no longer well adapted to the contemporary socio-political context in which, for example, many multinational corporations possess more monetary power than some entire States ${ }^{11}$.

Nevertheless, customary international law does present particular provisions that ultimately hold the State accountable for the conduct of non-State actors. For example, a State can be attributed responsibility for the conduct of a nonState actor when said actor - in its constitution or conduct - is so narrowly linked to the state in a particular situation that the conduct can be considered that of the state itself ${ }^{12}$. The CESCR also specifies that States should "prevent their own citizens and companies from violating the right to water in other countries ..."4. This is particularly relevant due to the trend, starting in the 1980s, to encourage the outsourcing of water and sanitation services to multinational companies. In the WATSAN sector this may also apply to non-governmental organizations (NGOs), which are common stakeholders that often operate with funding from developed States or multilateral organizations in partner states. In such cases, it may reasonably be considered that those stakeholders assume responsibilities to realize the HRtWS just as a State would be obliged to.

\section{Multilateral organizations: should or must?}

The broad human rights obligations of multilateral actors may be considered ambiguous in the absence of their explicit participation in a particular instrument of conventional human rights law. Regarding the HRtWS, such obligations have been the subject of controversy. This is particularly relevant for the World Bank (WB) and other regional banks, who are important funders responsible for consistent, significant flows of loans to the WASH sector. On the human right to water, the CESCR has stated that these organizations should "cooperative effectively with States parties, building on their respective expertise, in relation to the implementation of the right to water at the national level" ${ }^{\prime 4}$. Regarding the WB and IMF, the Committee has stated that they "should take into account the right to water in their lending policies, credit agreements, structural adjustment programmes and other development projects, so that the enjoyment of the right to water is promoted". Moreover, the CESCR has voiced several opinions calling on developed countries to do all they can "to ensure that the policies and decisions of those organizations are in conformity with the obligations of States parties" ${ }^{\prime 3}$ to the ICESCR. 
Although the human rights obligations of multilateral organizations are not made explicit in human rights treaties, or otherwise in customary international law, it is reasonable to infer their derived human rights-related obligations ${ }^{14}$. The strongest argument in this respect highlights the fact that 170 State Parties have signed or ratified the ICESCR in addition to other relevant international human rights instruments. Considering this, international financial institutions, regional banks and regional development organizations, all of which consist of Member States, should respect, protect and facilitate the human rights to water and sanitation through their activities. Recalling article 31 of the Vienna Convention, it could defeat the purpose of many human rights conventions if States' conduct via multilateral organizations was not held to the same standard as that determined by their membership to those conventions.

\section{An overview of development cooperation for WATSAN}

\section{Evolution of development cooperation in the sector}

The main framework for development cooperation in the WATSAN sector was established in the context of various meetings and policy documents dating back to the 1970s. The statement of the International Conference on Water and the Environment (Dublin, January 1992), together with the Agenda 21 of the United Nations Conference on Environment and Development (Rio de Janeiro, June 1992), are pillars on which subsequent international development programmes, such as the MDGs, have been based.

Notably, the Dublin Conference Report set out principles for action in the WATSAN sector at local, national and international levels. However, its two most influential principles - recognizing access to clean water and sanitation at an affordable price as a human right while also recognizing water as an economic good - were sufficiently ambiguous so as to accommodate a wide range of interpretations. As highlighted above, for many years following that declaration, several multilateral agencies' cooperation programmes wielded radical conditionalities including mandatory privatization of services and embodied a general view of water as a commodity. In a sense, many funders embraced the second part of the principles - the "economic side" - over the first one - "the rights side".
Funders' behavior in the WATSAN sector is increasingly relevant considering the ambitious 2030 Development Agenda and the fact that development cooperation in the WATSAN sector is rapidly gaining more devoted attention internationally. In the WATSAN sector, during the period 2006-2015, disbursements from all States and multilaterals increased in all but two years, from $\$ 3.9 \mathrm{~b}$ in 2006 to $\$ 6.6 \mathrm{~b}$ in 2015 , reaching $\$ 7.2 \mathrm{~b}$ in 2014. Bearing in mind, as a sector among all development cooperation funds, WATSAN is still a relatively small part of a greater picture; in 2015, disbursements to the WATSAN sector represented just under 4 percent of all development cooperation flows ${ }^{15}$.

\section{Caveats to apparent evolution in the sector}

Looking closer at the trend of growing funding for the WATSAN sector through international cooperation, a few important nuances are relevant from a human rights standpoint. Firstly, in the 2006-2015 period grants consistently waned in popularity against concessional loans. In 2015, about $46 \%$ of funds disbursed to the WASH sector were grants compared to approximately $53 \%$ of funds that were distributed as loans. In 2006, grants represented $65 \%$ of funding and loans $34 \%{ }^{15}$. It may be argued that development cooperation takes on a different character when provided with or without the expectation of a financial return to the funder, for at least two reasons. Firstly, loans likely benefit the most well-off as, to recover the funds required to pay back the loan, full cost recovery policies are usually applied via tariffs paid by users, the poorest of whom often sacrifice a greater portion of their income to access these essential services. In connection with this point, projects benefiting the most impoverished are unpopular candidates for loans due to the attendant difficulty in achieving full cost recovery from such user bases. Secondly, loans can otherwise impact on users who may be broadly responsible for reimbursing them through general tax payments.

Critical reviews of development cooperation flows also indicate that the available data may be fragmented at best ${ }^{16}$. For instance, the majority of development projects registered in the OECD database for the WATSAN sector - accounting for more than half the amount of funds dedicated to this sector - do not clearly indicate whether rural or urban areas are targeted ${ }^{17}$. Considering the markedly worse levels of access to adequate WATSAN services in rural areas as compared to urban areas, filling this information gap could 
significantly help developers in understanding shortcomings in this area.

An analysis of fund distribution according to the main categories for development cooperation to the WATSAN sector (water resources policy and management; large water supply and sanitation systems; basic water supply and sanitation systems; and education and training) suggests that rural areas receive much less funding than urban areas. Despite growing levels of development cooperation for WASH, two adverse factors are recognized: real quantities of cooperation are still insufficient and the methods of targeting cooperation are debatable at best to contribute to achieving universal coverage of the world's needs for water and sanitation ${ }^{18}$. Disbursements to basic systems, a common proxy indicator for systems that reach a lesser number of users - generally the urban poor, dwellers of informal settlements and rural inhabitants ${ }^{19,20}$ - are consistently less than those to large systems, which target larger clusters of urban users.

Moreover, although the importance of education and training for stakeholders involved in the provision of WATSAN services has long been highlighted as a key to ensuring sustainability, OECD data reveals that this subsector receives an insignificant proportion of WASH funding. In fact, among all funding by States and multilaterals to this subsector, between 2010 and 2014 more than half was provided by Denmark and Netherlands alone ${ }^{15}$.

Finally, significant proportions of development cooperation are also channeled through NGOs and civil society, multilateral organizations, public-private partnerships, and private contractors. In the WATSAN sector, data reveals a variable trend of majority funding through public entities; in 2006, 51 percent of funds were channeled through a public entity in developed States, in 2011 this figure was 83 percent, in 2015 it was 74 percent $^{15}$. Significant bypassing of a State's authorities can be worrying as it may signify weak country ownership of projects and a barrier to creating stronger States.

\section{Least Developed Countries require more preferential attention}

The LDCs are a fluctuating group of some 48 States to whom the UN organization devotes special attention for their particularly adverse situation regarding essential social and economic development criteria. In 2001, it was agreed at the Third United Nations Conference on Least Developed Countries that international coopera- tion is crucial to lift countries out of LDC status. As a part of the MDG agenda, Goal 8 was in large part dedicated to boosting the LDCs' out of their starkly unequal standing in the world, including through the promotion of more generous development cooperation.

However, attaining some other MDG targets, such as reducing the percentage of the population without adequate water or sanitation services by $50 \%$ (target 7.C), was often more challenging for the LDCs than for other more developed countries given that the latter often had a far lesser proportion of people requiring improved access. Indeed, among the MDG targets that were not met by the LDCs, target 7.C was a resounding failure for many States, with few exceptions in the Asian LDCs (e.g. Bhutan, Sao-Tome and Principe, and Tuvalu achieved significant progress in universalizing improved drinking water services). Overall, 49 percent of the population in LDCs gained access to improved water sources since 1990, leaving a total access level of 69 percent for the group. Only 27 percent of the LDC population gained access to improved sanitation since 1990, making their total access level a mere 37 percent.

The UN Office dealing with Least Developed Countries, Landlocked Developing Countries and Small Island Developing States (UNOHRLLS) concluded that most LDCs did not accomplish the MDGs in general due to a lack of focus on MDG $8^{21}$. This directly implicates the way in which development cooperation was carried out by many developed countries, although the UN also stresses the mutual responsibility of LDCs and development partners to establish structured dialogue on the roles and responsibilities of each stakeholder in development relationships ${ }^{22}$. Halfway through the MDG period, in 2008, this outcome had already been foreseen. The international NGO WaterAid warned that less than a quarter of development cooperation aid to the WATSAN sector was being allocated to the LDCs, proposing a global framework for action to "recalibrate development priorities"20. Shortly after this period, supposedly owing to the global economic crisis, overall international cooperation flows dropped significantly in 2011, particularly affecting the LDCs. While flows gradually recovered over the next few years, they nevertheless did not attain the total levels reached in $2008^{22}$. Throughout recent years, the funding provided by developed countries to LDCs has not been constant and arguably continues to be insufficient to meet those countries' needs for adequate water and sanitation services. This is evi- 
denced notably by developed countries' failure to attain the MDG target of providing at least 0.15 percent of their gross national income (GNI) in cooperation to the LDCs. By 2014, only eight developed countries had done so, down from ten in 2011. Worse still, the average share of cooperation to LDCs was only 0.09 percent of developed countries' collective GNI in $2014^{22}$.

The types of services to which funds were allocated for the LDCs' WATSAN sector were slightly more encouraging as compared to the trends in all other countries. In 2014, 41 percent of funding to the LDCs was allocated to large water supply and sanitation activities (compared to $47 \%$ overall) and 32 percent to basic drinking water supply and sanitation (compared to $26 \%$ overall $)^{15}$. If there is indeed any cause for encouragement, it may be derived from the hope that a greater proportion of funding going to basic systems will translate into improved coverage levels in the LDCs' rural areas, which by far suffer most from lack of adequate access. The inequalities characterizing the LDCs thus follow similar patterns as the overall global trends albeit with worse real access levels, suggesting a more intensified need for targeted efforts to the sanitation sector and to rural, informal urban, and possibly poor urban populations.

\section{The HRtWS in development cooperation policies}

\section{Situating the HRtWS in Development Cooperation}

Inequalities, discriminatory practices, and unjust distributions of power can lie at the heart of development problems and impede development progress ${ }^{23}$. While human rights law clearly requires States to respect, protect and fulfil all human rights in projects they finance both in their nation and abroad, the human rightsbased approach in development cooperation to the WATSAN sector is still not well incorporated by policy makers, sector experts or practitioners. This is confirmed by a broad review of States' and multilateral agencies' policy documents, in addition to communications with national governments and civil society input on this particular subject $^{24}$.

Some civil society organizations have qualified development cooperation in the WATSAN sector as apt to frequently disregard human rights principles including transparency, access to in- formation, and non-discrimination, and the normative content of the related human rights such as ensuring service affordability. For example, several Mexican civil society organizations raised concerns related to a lack of transparency and a general neglect of the principle of sustainability:

Despite advances in coverage for piped running water in the region, guaranteeing the full exercise of the human right to water and sanitation still constitutes an enormous challenge for public authorities as a commercial, patronage politics vision of infrastructure prevails, as opposed to one based on the sustainable and democratic management of [water] (translated from Spanish by authors) ${ }^{25}$.

Projects in this sector may also evoke even broader human rights concerns, such as the protection of individuals' right to freedom of expression and of human rights defenders. For example, threats to individuals' freedom, and even their lives, are reported when they voice concerns for human rights in connection to projects coordinated via multilateral development cooperation in the WATSAN sector ${ }^{26}$.

\section{HRtWS in State and multilateral agency policies}

A non-exhaustive review of development cooperation policies, as formulated in official documents of main funder States and multilateral agencies, reveals slightly heterogeneous tendencies. Human rights are commonly recognized in a general fashion in funders' policy documents. However, more specific human rights obligations related to specific sectors, like water and sanitation, are less frequently backed by clear methodologies that set out how to protect, respect and fulfil human rights, for example, in their operational plans or monitoring. Policies do sometimes display adherence to several principles such as equality and non-discrimination, access to information, participation and accountability. Yet they most frequently do so without referring in any depth to their corresponding obligations under international human rights law. Similarly, policies regarding the WATSAN sector occasionally address some normative content of the HRtWS, such as guaranteeing water quality and availability, but other aspects including affordability and accessibility are systematically absent.

Many developed countries emphasize the importance of human rights in their development cooperation policies. The way in which this is formulated in United Kingdom policy can be taken as a representative example of many oth- 
er countries (e.g. Finland, Germany, Republic of Korea, Denmark, Austria, Canada, France): “an effective aid partnership is based on a shared commitment to...respecting human rights and other international obligations...Donors have a particular responsibility, as part of their accountability to parliament and the public, to ensure that their development assistance is not used in ways that abuse human rights" 27 .

Much fewer States have specifically recognized economic, social and cultural human rights, such as the HRtWS, in the context of their policies for development cooperation. The Netherlands is among a few countries, such as Japan, Sweden and Spain, with policy stating that the State "...recognized the right to safe drinking water and sanitation as a basic human right" and that the "recognition of that right grants the Netherlands, in policy discussions with partner countries, the right to point out the responsibilities of the government and the rights of the population, in particular the vulnerable groups" ${ }^{28}$.

Other relevant, soft political commitments have been made by States in the OECD. Policy papers and resolutions have, for example, reaffirmed States' obligations stemming from international human rights law and their consequent duty to incorporate human rights into development cooperation-related decisions, including in the WASH sector ${ }^{29}$.

However, experiences are limited of development cooperation projects in the WATSAN sector that attempt to put such commitments and obligations of States into practice, for example by applying a human rights-based approach (HRBA). Notable resources have been prepared by the German Corporation for International Cooperation (GIZ) ${ }^{30}$ as well as the Swiss Development Cooperation and UN-Habitat ${ }^{31}$.

A review of major multilateral agencies' policies reveals less apparent willingness to align their development cooperation policies with the human rights framework. Some multilateral agencies' policy documents show some relative similarities to that of States, such as the European Union $^{32}$ and African Development Bank ${ }^{33}$. Like States, detailed experiences of projects or programmes performed by multilaterals with a basis in the human rights framework are limited. Most encouraging are the efforts of some UN agencies who have been working for more than a decade to grow experiences of applying the HRBA in all development sectors, including in WATSAN, and to define this methodology as a central orientation for all future development cooperation ${ }^{34}$.
Other major multilateral funders, such as the WB, abstain from explicitly tying the HRtWS to their development cooperation policies. This may seem to contradict the Bank's broad goals of ending extreme poverty and boosting shared prosperity. It stands that the human rights framework is conspicuously and systematically absent from the organization's projects, including in its operational policies, safeguard policies, implementation agreements, and social and environmental assessments. Moreover, there has been no shortage of occasions, such as the recent updating of the WB's Social and Environmental Framework, during which diverse groups emphasized their desire that the Bank include human rights-related criteria in its Operational Policies.

Funders' possible resistance to the human rights framework may be explained by the fact that fulfilling its principles would risk making it harder for programmes and projects to "push money out of the door", a behavior associated with the WB's conduct ${ }^{35}$. It is in this light that some civil society groups have scrutinized the human rights impacts of development cooperation, even when it is carried out by funders with ostensibly human rights-friendly policies. For instance, it has been pointed out that the United Kingdom overwhelmingly directs foreign aid funds to private enterprises; in 2014, about $75 \%$ of UK bilateral aid to Nigeria went through private sector companies, with $20 \%$ being spent through multilateral organizations and only $5 \%$ through civil society organizations ${ }^{36}$. As expressed above, the application of aid via such channels has been criticized for presenting a number of risks: that users may pay more for services in order to ensure profits for the private companies, and that the systematic bypassing of the public sector keeps it in a secondary role and prevents the partner State from building strength and reaffirming ownership of such projects.

\section{Country ownership and conditionalities}

Part of the literature on conditionalities in development cooperation identifies either positive or negative outcomes to their use $\mathrm{s}^{37}$. However, a relevant body of research has highlighted that bilateral and multilateral funders have imposed conditionalities in development cooperation programmes that resulted in negative repercussions on the foundations of democratic governance within the partner countries ${ }^{38}$. Common conditionalities for such WATSAN projects include ex-ante or ex-post, policy-based, out- 
put-based or tied-aid. These mechanisms are essentially grounded in an economic concern to guarantee "efficiency", or financial returns. For example, a funder may condition aid for a collective water supply system on the raising of tariffs paid by users, a policy of full-cost recovery, or the privatization of service provision.

There is a growing call to end these practices in the interest of ensuring country ownership. For example, during the intergovernmental International Conference on Freshwater it was determined that "[p] rivate sector participation should not be imposed on developing countries as a conditionality for funding", and that priority should be raised to catalyze other finances, build capacity, and target the poor, especially in rural areas ${ }^{39}$. Indeed, several concerns have been raised regarding the participation of private entities in the provision of water and sanitation services ${ }^{40}$. For example, conditionalities imposed by funders requiring full-cost recovery through tariffs have unfairly raised the cost of access to WATSAN services, compromised affordable access to the poorest demographics, excluded projects benefiting low-income populations and prevented any recourse for affected residents to petition these measures. Even those organizations that reluctantly acquiesce to controls on development cooperation and perceive human rights safeguards as excessively zealous measures nonetheless recognize that conditionalities can be unfair, especially when funders impose their own consultants, suppliers or methods of work ${ }^{41}$.

\section{Conclusion}

The WATSAN sector is verifiably receiving increased attention and funding through international development cooperation. The human rights framework is consolidating around that sector and is being linked to the world's most significant and coordinated development efforts, arguably with greater clarity than ever. The specific human rights frameworks for these rights are only partially endorsed in major funders' policies for development cooperation, likely owing to the State-centric nature of human rights law. In that respect, many more funder States provide greater evidence than major multilateral organizations, with a few exceptions, of recognizing the human rights framework and committing to make it translate through their development cooperation projects and programmes for the WATSAN sector. Practical evidence of human rights-based approaches in development cooperation programmes in the WATSAN sector are still scarce.

Funding to the WATSAN sector via development cooperation is distributed unequally, most likely benefiting dense urban populations in detriment of demographics living in rural, informal urban or poor urban settings. Taking into consideration the fundamental role that development cooperation possesses for developing countries, such inequalities raise concerns for the human rights of the unserved and underserved. The evidence suggesting that funders only poorly or partially adopt the human rights framework in their policies could be the basis for a preliminary hypothesis that a more effective incorporation of that framework would reduce unequal benefits of development cooperation for this sector. Policies that adopt the specific frameworks of the HRtWS would likely provide greater funds to sanitation than water, to basic systems rather than large systems, and would invest considerably more in education and training. They would also prioritize projects aiming at providing universal access to these services, with particular emphasis on guaranteeing access for the most vulnerable populations. Moreover, it would necessarily emphasize the strengthening of governments in partner States who receive aid, working to reinforce their legal, policy and regulatory framework, and empowering them to reaffirm country ownership. 


\section{Collaborators}

CA Brown prepared the draft, performed research, and performed final editing. L Heller helped in preparing the draft and performed several reviews.

\section{Acknowledgements}

We wish to thank Madoka Saji from the OHCHR in Geneva and Ashfaq Khalfan from Amnesty International for their invaluable guidance and Nicolas Bourlon for his technical assistance.

\section{References}

1. United Nations (UN). The Vancouver Declaration on Human Settlements, From the report of Habitat: United Nations Conference on Human Settlements Vancouver, Canada, 31 May to 11 June 1976. Vancouver: UN; 1976.

2. Langford M, Winkler I. Quantifying Water and Sanitation in Development Cooperation: Power or Perversity? Harvard School of Public Health Working Paper Series May 2013; 23:20.

3. United Nations Committee on Economic, Social and Cultural Rights (CESCR). General Comment No. 15: The Right to Water (Arts. 11 and 12 of the Covenant). Geneva: UN CESCR; 2003. UN Document E/C.12/2002/11

4. United Nations General Assembly (UNGA). Human Right to Water and Sanitation. Geneva: UNGA; 2010. UN Document A/RES/64/292.

5. United Nations General Assembly (UNGA). Transforming Our World: the 2030 Agenda for Sustainable Development. Geneva: UNGA; 2015. UN Document A/70/1.

6. United Nations Conference on Trade and Development (UNCTAD). The Least Developed Countries Report 2014 - Growth with structural transformation: A post2015 development agenda. Geneva: UNCTAD; 2014.

7. United Nations General Assembly (UNGA). Report of the Spec. Rapp. on the Human Rights to Safe Drinking Water and Sanitation. UNGA; 2016. UN Document A/71/302.

8. United Nations Committee on Economic, Social and Cultural Rights (CESCR). Guidelines on Treaty-specific Documents to be Submitted by States Parties under Articles 16 and 17 of the International Covenant on Economic, Social and Cultural Rights (Forty first session, 2008). Geneva: UN CESCR; 2009. UN Document E/C.12/2008/2 at para. 9 .

9. De Schutter O, Eide A, Khalfan A, Orellana M, Salomon M, Seidermanf I. Commentary to the Maastricht Principles on Extraterritorial Obligations of States in the Area of Economic, Social and Cultural Rights. Human Rights Quarterly 2012; 34(2012):1084-1169.

10. Office of the United Nations High Commissioner for Human Rights (OHCHR). Guiding Principles on Business \& Human Rights: Implementing the United Nations "Protect, Respect and Remedy" Framework. Geneva: OHCHR; 2011.

11. Hessbruegge J. Human Rights Violations Arising from Conduct of Non-State Actors. Buffalo Human Rights Law Review 2005; 11:21-88.

12. International Law Commission. Draft Articles on Responsibility of States for Internationally Wrongful Acts. Yearbook of the International Law Commission 2001; 2(2).

13. United Nations Committee on Economic, Social and Cultural Rights (CESCR). Concluding Observations of the Committee on Economic, Social and Cultural Rights: Germany. Geneva: UN CESCR; 2001. UN Document E/C.12/1/Add.68, para. 31 .

14. Brodnig G. The World Bank and Human Rights: Mission Impossible? The Fletcher Journal of Development Studies 2002; 13:1-15.

15. Organization for Economic Co-Operation and Development (OECD). Creditor Reporting System [Online database] [cited $2017 \mathrm{Feb}$ 13]. Available from: http:// stats.oecd.org/Index.aspx?QueryId $=58195$ 
16. Easterly W, Pfutze T. Where Does the Money Go? Best and Worst Practices in Foreign Aid. Journal of Economic Perspectives 2008; 22(2):29-52.

17. Ntawiha W. People in rural areas risk being left behind as aid to water and sanitation appears to provide better support to urban areas. Development Initiatives [website] 22 Mar 2016 [cited 2016 Aug 2]. Available from: http://devinit.org/news/\#!/post/world-water-day-2016.

18. Organization for Economic Co-Operation and Development (OECD). Financing Water and Sanitation in Developing Countries: The contribution of external aid. OECD-DAC: June 2013 [cited 2016 Oct 17]. Available from: http://www.oecd.org/dac/stats/Brochure_water_2013.pdf.

19. WaterAid, Tearfund. Sanitation and water: Why we need a global framework for action. London: WaterAid; 2008.

20. WaterAid. Essential element: why international aid for water, sanitation and hygiene is still a critical source of finance for many countries. London: WaterAid; 2015.

21. United Nations Office of the High Representative for the Least Developed Countries, Landlocked Developing Countries and Small Island Developing States (UN-OHRLLS). State of the Least Developed Countries 2016. New York: UN-OHRLLS; 2016.

22. United Nations General Assembly (UNGA). Smooth transition for countries graduating from the list of least developed countries. UNGA; 2013. UN Document A/ $\mathrm{RES} / 67 / 221$

23. Office of the United Nations High Commissioner for Human Rights (OHCHR). Frequently Asked Questions on a Human Rights-Based Approach to Development Cooperation. Geneva: OHCHR; 2006.

24. Office of the United Nations High Commissioner for Human Rights (OHCHR). Development Cooperation [website] n/d [cited 27 Sep 2016]. Available from: http://www.ohchr.org/EN/Issues/WaterAndSanitation/ SRWater/Pages/DevelopmentCooperationSubmissions.aspx

25. Coalicion de Organizaciones Mexicanas por el Derecho al Água (COMDA), Red de Género y Medio Ambiente, Caminos Alternativos de Educación Ambiental Veredas. Aportes desde México para el Informe sobre igualdad de género y DHAS ONU [communiqué] n/d [cited 27 Sep 2016]. Available from: http://www.ohchr.org/ Documents/Issues/Water/ContributionsDevelopmentCooperation/Several_Mexican_civil_society_organizations.pdf

26. Human Rights Watch. At Your Own Risk: Reprisals against Critics of World Bank Group Projects [online report] June 22 2015. [cited 2016 Jul 22]. Available from: https://www.hrw.org/report/2015/06/22/yourown-risk/reprisals-against-critics-world-bank-groupprojects

27. United Kingdom (UK), Department for International Development. Partnerships for Poverty Reduction: Rethinking Conditionality, UK Policy Paper. London: DFID; 2005

28. Netherlands. Ministry of Foreign Affairs (MFA). From infrastructure to sustainable impact: Policy review of the Dutch contribution to drinking water and sanitation 1990-2011. The Hague: MFA; 2012.
29. Organization for Economic Co-Operation and Development (OECD). "OECD Principles on Water Governance". [cited 2016 Jul 22]. Available from: http:// www.oecd.org/gov/regional-policy/OECD-Principles-on-Water-Governance-brochure.pdf

30. Germany Technical Cooperation Agency (GTZ). The Human Right to Water and Sanitation - Translating Theory into Practice. Eschborn: GTZ; 2009.

31. Centre on Housing Rights and Evictions (COHRE), American Association for the Advancement of Science (AAAS), Swiss Agency for Development and Cooperation (SDC), United Nations Human Settlements Programme (UN-HABITAT). Manual on the Right to Water and Sanitation. Geneva: COHRE; 2007.

32. European Commission (EC). The European Union Explained: International Cooperation and development. Brussels: EC; 2014.

33. African Development Bank (AfDB). Strategic Plan 2012 - 2015: Delivering Basic Water Supply and Sanitation to Rural Africa. Tunis: AfDB; 2012.

34. United Nations Educational, Scientific and Cultural Organization (UNESCO). Undertaking a Human Rights-Based Approach: A Guide for Basic Programming - Documenting Lessons Learned for Human RightsBased Programming: An Asia-Pacific Perspective. Bangkok: UNESCO Bangkok; 2008.

35. United Nations General Assembly (UNGA). Report of the Spec. Rapp. on Extreme Poverty and Human Rights. UNGA; 2015. UN Document A/70/274.

36. Provost C. The Privatisation of UK aid: How Adam Smith International is profiting from the aid budget. London: Global Justice Now; 2016.

37. Koch S. A Typology of Political Conditionality Beyond Aid: Conceptual Horizons Based on Lessons from the European Union. World Development 2015; 75:97-108.

38. United Kingdom (UK). Partnerships for Poverty Reduction: Rethinking Conditionality. London: UK; 2005. UK Policy Paper.

39. International Institute for Sustainable Development (IISD). Summary of the International Conference on Freshwater, 3-7 December 2001. Sustainable Development 2001: 66(5):1-11.

40. Petrova V. All the Frontiers of the Rush for Blue Gold: Water Privatization and the Human Right to Water. Brooklyn Journal of International Law 2006: 31(2):577613.

41. AquaFed. AquaFed contribution on questions for the report on Development Cooperation. 30 Jan 2016. [cited 27 Sep 2016]. Available from: http://www.ohchr. org/Documents/Issues/Water/ContributionsDevelopmentCooperation/AquaFed.pdf

Artigo apresentado em 20/09/2016

Aprovado em 28/11/2016

Versão final apresentada em 06/03/2017 